\title{
MODELIRANJE I PRORAČUN PRIKLJUČAKA U SPREGNUTIM KONSTRUKCIJAMA
}

\section{Andrea Abičić}

Sveučilište J.J. Strossmayera u Osijeku, Građevinski fakultet Osijek, student

\section{Damir Markulak}

Sveučilište J.J. Strossmayera u Osijeku, Građevinski fakultet Osijek, prof.dr.sc.

\section{Ivan Radić}

Sveučilište J.J. Strossmayera u Osijeku, Građevinski fakultet Osijek, dipl.ing.građ.

Sažetak: U radu se opisuje način modeliranja i proračuna priključaka kod spregnutih konstrukcija čelik-beton, u skladu s Eurokod normama HRN EN 1993-1-8:2008 i HRN EN 1994-1-1:2008. Komentiraju se različite varijante izvedbe priključaka te specifičnosti primjene metode komponenata iz HRN EN 1993-1-8:2008 na proračune spregnutih priključaka. Na numeričkom primjeru je ilustriran kodificirani proračun dvostranog spregnutog priključka.

Ključne riječi: spregnute konstrukcije čelik-beton, dvostrani priključci, metoda komponenata, uzdužna armatura

\section{MODELING AND CALCULATION OF CONNECTIONS IN COMPOSITE STRUCTURES}

Abstract: The paper describes modeling and calculation of connections in composite steel-concrete structures in accordance with the Eurocode design standards HRN EN 1993-1-8:2008 and HRN EN 1994-1-1:2008. Commenting on the different variants of connections and specific application of the method in HRN EN 1993-18:2008 to the calculation of composite connections. A numerical example is given in order to illustrate codified design of two-sided composite connections.

Key words: composite steel and concrete structures, two-sided connections, component method, longitudinal reinforcement 


\section{Općenito}

Suvremene norme za čelične i spregnute konstrukcije zahtijevaju uzimanje u obzir ponašanje priključaka pri definiranju proračunskih modela, pri čemu se analizira utjecaj ponašanja priključaka na raspodjelu reznih sila, odnosno globalno ponašanje sustava. U posljednje vrijeme ovoj je problematici posvećena velika pozornost pa su razrađeni postupci za preciznije procjenjivanje mehaničkih svojstava priključaka i njhovo uključivanje u proračune. Otpornost spojeva uglavnom nije upitna jer se primjenjuju dobro istražena načela za različite vrste spojeva, ali treba voditi računa o utjecaju elastičnog ili plastičnog popuštanja spoja koje se odražava na raspodjelu sila u čvorovima okvira ili nad srednjim ležajima kontinuiranih nosača.

lako je ponašanje priključka trodimenzionalno, uobičajena prisutnost krute stropne ploče obično omogućava konstruktoru da zanemari deformaciju izvan ravnine i torzijsku deformaciju priključka. Ponašanje priključaka i konstrukcijskih elemenata u konstrukcijama mora biti međusobno usklađeno. Priključak se u globalnom numeričkom modelu konstrukcije može prikazati kao rotacijska opruga koja povezuje težišne linije spojenih elemenata u točki njihova presjeka. Proračunske vrijednosti te rotacijske opruge mogu se odrediti iz odnosa momenta savijanja $M_{j, E d}$ koji djeluje na priključak i odgovarajuće rotacije priključka $\Phi_{E d,}$ [1]. Konstruiranje spregnutih priključaka se općenito može podijeliti na dva osnovna pristupa (slika 1):

- konstruiranje priključaka kao kod običnih čeličnih konstrukcija

- suvremena izvedba spregnuth priključaka kod kojih se ostvaruje kontinuitet međukatne konstrukcije, pri čemu čelična greda može biti ispod betonske ploče ili integrirana u međukatnu konstrukciju (tzv. slim floors).

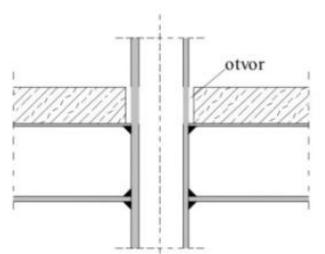

zavareni
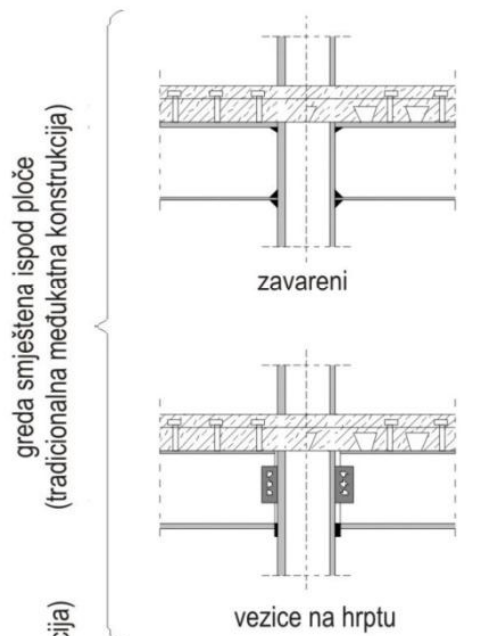

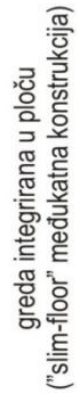

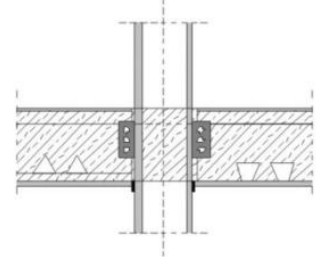

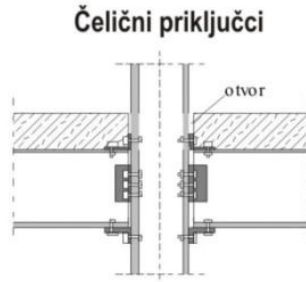

L-profili spojeni vijcima

Suvremena izvedba:

Spregnuti priključci
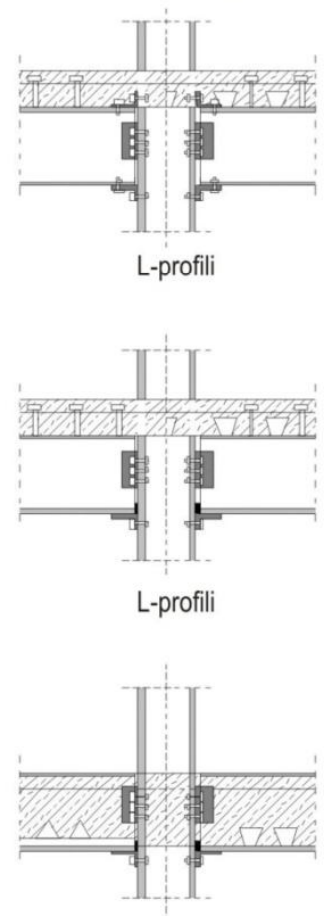

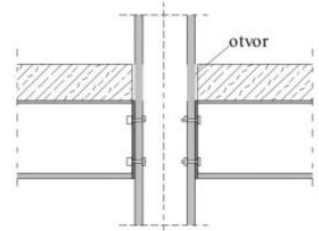

čelna ploča

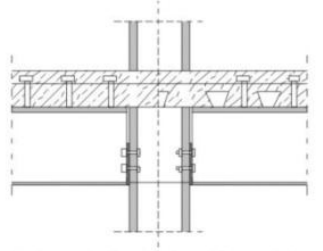

čelna ploča djelomične visine
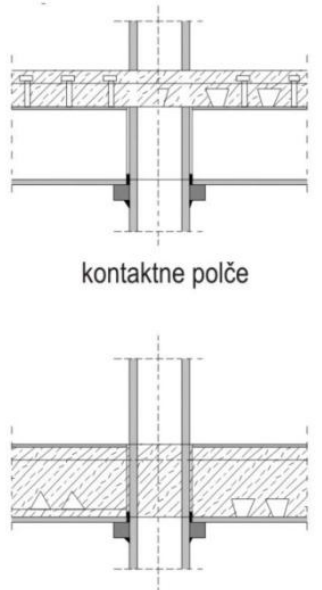

Slika 1 - Tipovi spregnutih priključaka 
Kod suvremene je izvedbe osnovni zahtjev osiguranje kontinuiranog djelovanja armature ploče u vlaku oko čvora, iako se općenito kod spregnutih okvira ne može postići puni kontinuitet između međukatne konstrukcije i stupova. Stoga su spregnuti priključci po svojoj prirodi općenito djelomično kontinuirani. Suvremena izvedba omogućuje ostvarenje puno većih vrijednosti krutosti i otpornosti.

Spojevi se izvode u zavarenoj ili vijčanoj varijanti pomoću čelnih ploča (u punoj ili djelomičnoj visini) ili L profila, a moguća je i izvedba s kontaktnim pločama. Kada su grede integrirane u međukatnu konstrukciju, preporuča se izvedba zglobnih spojeva sa stupom koji nakon betoniranja automatski postaju djelomično kontinuirani priključci. Daljnje povećanje krutosti i otpornosti priključka može se postići ubetoniravanjem hrpta stupa (betonom obloženi stupovi).

\section{Metoda komponenti kod spregnutih priključaka}

Model komponenti za čelične priključke, a kasnije i za spregnute priključke, razvijen je razmatranjem najboljeg načina za podjelu složenog konačnog spoja na logične dijelove, s obzirom na način ponašanja. Iz slike 2 vidi se da u priključku greda-stup postoje područja vlaka, tlaka i posmika. Općenito se za određivanje proračunskih karakteristika priključaka koristi metoda komponenata koja se sastoji u tome da se priključak modelira sustavom sastavljenim od krutih i popustljivih komponenata. Za svaku se komponentu odvojeno procjenjuju karakteristike otpornosti, krutosti i duktilnosti. Komponente iz pojedinih područja rade zajedno te se njihove karakteristike serijski vežu. Tada se dobivene karakteristike pojedinih područja međusobno kombiniraju radi modeliranja mehaničkih karakteristika čitavog priključka.

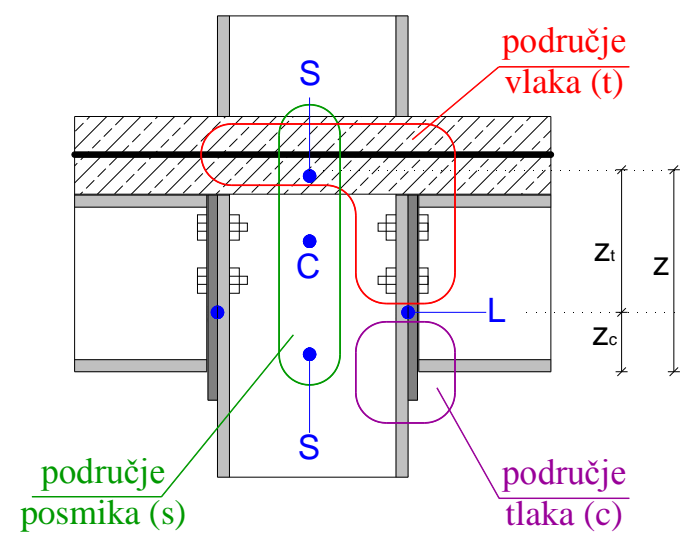

\section{Slika 2 - Područja otpornosti u spregnutom priključku}

$\mathrm{U}$ [2] je zasada dana 21 različita osnovna komponenta priključka s detaljnom analitičkom procedurom određivanja karakteristika priključaka potrebnih za proračun konstrukcije. U [3] se u poglavlju o priključcima daju samo posebnosti spregnutih priključaka, dok se za ostale podatke upućuje na [2] i [4], te se posebno naglašava da se sve navedeno odnosi na pretežito statičko opterećenje.

Kod modeliranja ponašanja priključaka, red armature u vlaku može se tretirati na isti način kao i red vijaka u običnom čeličnom priključku, naravno uvažavajući mehaničke i geometrijske karakteristike armature. Pri određivanju rotacijskog kapaciteta priključka u obzir treba uzeti utjecaj raspucavanja betona, vlačnog očvršćivanja i deformaciju moždanika, a za nestandardne priključke treba izvršiti eksperimentalno ispitivanje predloženog rješenja. Što se tiče samog proračuna otpornosti i krutosti pojedinih osnovnih komponenti spregnutih priključaka, u [3] se, uz već postojeće osnovne komponente u [2], dodaju još dvije:

- uzdužna armatura u vlaku i

- čelična kontaktna ploča u tlaku.

Pri proračunima se pretpostavlja da je vlačna armatura u efektivnoj širini betonske pojasnice napregnuta do granice popuštanja, a za slučaj neuravnoteženog opterećenja primjenjuje se tzv. strut-tie model za provjeru unosa sila u betonsku ploču oko stupa. 
lako se ne navodi kao posebna komponenta, u obzir se uzima i betonska obloga stupa ako postoji, te se daju izrazi za proračun posmične otpornosti obložnog betona za slučaj jednostranih priključaka i dvostranih priključaka s gredama jednake visine. Kod priključaka s kontaktnom pločom, raspodjela reznih sila u priključku je vrlo jednostavna, budući da čelična greda ne sudjeluje u prijenosu vlačnih naprezanja (slika 3).

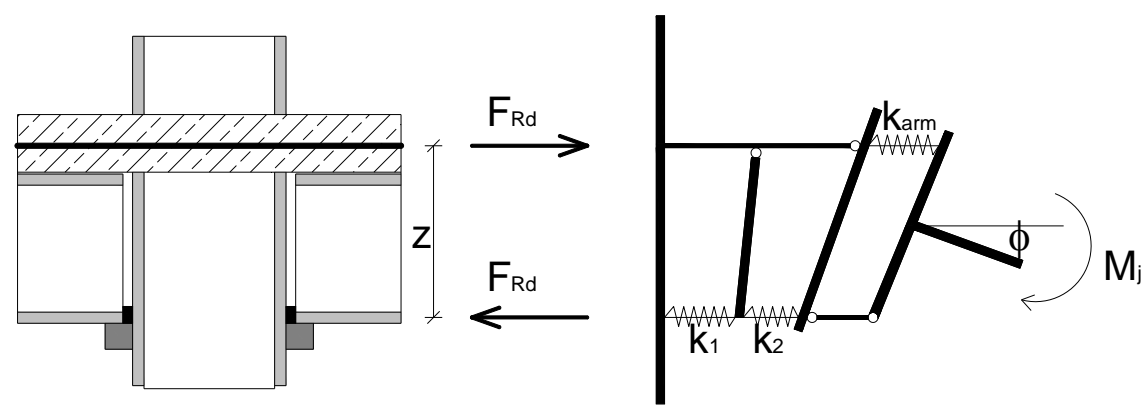

\section{Slika 3 - Priključak s čeličnim umetkom i jednim redom armature}

Međutim, kod priključaka kod kojih čelična greda sudjeluje u prijenosu vlačnih naprezanja od savijanja, situacija je bitno složenija, a obično se pretpostavlja da porastom momenta savijanja armatura prva doseže proračunsku otpornost. Stoga je tečenje armature u vlaku kod spregnutih priključaka osnovno polazište za procjenu rotacijskog kapaciteta pa je potrebno ugraditi visoko duktilnu armaturu kako bi se omogućila preraspodjela vlačnih sila u priključku i na vlačne redove vijaka na čeličnoj gredi.

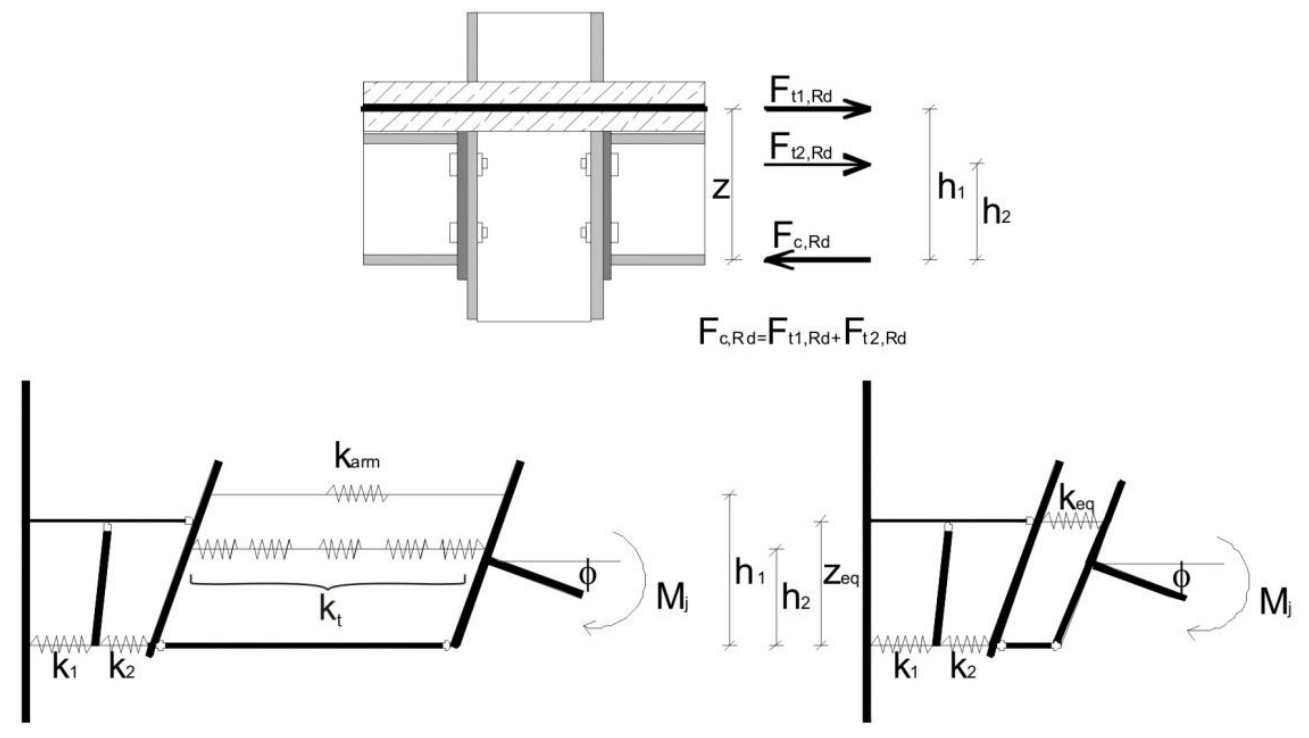

Slika 4 - Priključak s čelnom pločom visine hrpta

Zbog pojednostavljenja proračuna, nekoliko komponenti grupira se u pojedine skupine te se u konačnici sve pokazuje ekvivalentnim sustavom tlačnih i vlačnih sila na ekvivalentnom kraku sila $z_{e q}$, slika 4 . Oznake na slici imaju sljedeće značenje:

$k_{\text {eq }}$ - koeficijent svih vlačnih komponenti priključka

$k_{t}$ - koeficijenti krutosti hrpta stupa u vlaku, pojasnice stupa u savijanju, čelne ploče u savijanju, hrpta grede u vlaku i vijaka u vlaku

$k_{\text {arm }}$ - koeficijent vlačne armature

$h_{1}, h_{2}$ - krakovi unutarnjih sila pojedine vlačne komponente

$k_{1}, k_{2}$ - koeficijenti krutosti koji se odnose na hrbat stupa izložen posmiku i neukrućeni hrbat stupa izložen tlaku. 
Ekvivalentni krak sila može se računati iz sljedećih odnosa:

$$
\begin{aligned}
& k_{t}=\frac{1}{\sum \frac{1}{k_{i}}} \\
& k_{e f f, r=1}=k_{\text {arm }} \\
& k_{\text {eff }, r=2}=k_{t} \\
& z_{e q}=\frac{\sum_{r}^{r} k_{e f f, r} \cdot h_{r}^{2}}{\sum_{r} k_{e f f, r} \cdot h_{r}}=\frac{k_{a r m} \cdot h_{1}^{2}+k_{i} \cdot h_{2}^{2}}{k_{a r m} \cdot h_{1}+k_{i} \cdot h_{2}} \\
& k_{e q}=\frac{\sum_{r} k_{e f f, r} \cdot h_{r}}{z_{e q}}=\frac{k_{a r m} \cdot h_{1}+k_{i} \cdot h_{2}}{z_{e q}}
\end{aligned}
$$

\section{Problematika dvostranih priključaka}

Kod dvostranih priključaka, hrpteni panel stupa sudjeluje u ponašanju priključaka i s lijeve i desne strane, te je za modeliranje takvih priključaka potrebno utvrditi:

- karakteristike lijevog priključka

- karakteristike desnog priključka

- karakteristike posmičnog panela hrpta stupa.

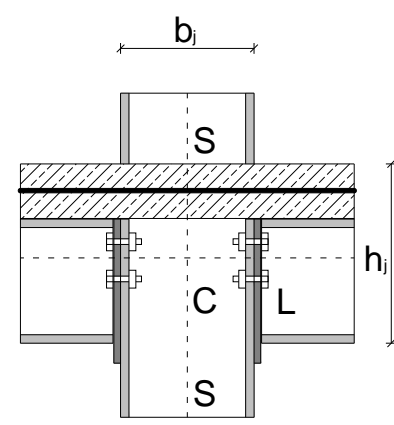

a)

stvarni priključak

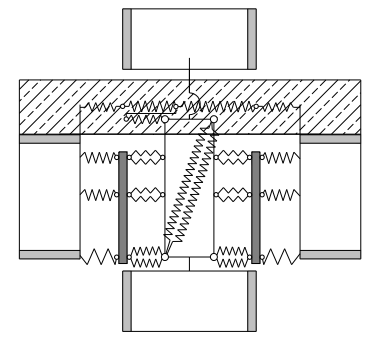

b) komponenti

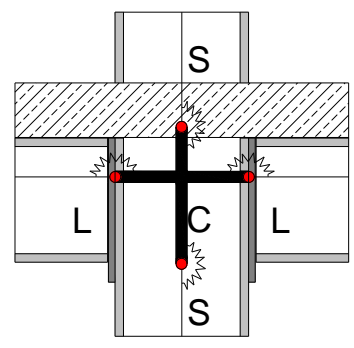

c)

konačni model priključka

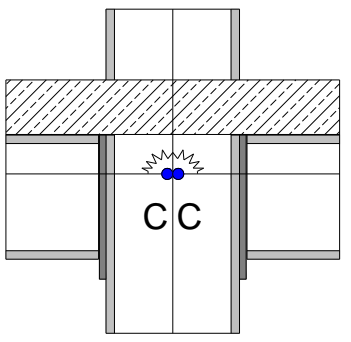

d)

koncentrirani model prključka

\section{Slika 5 - Modeliranje priključka}

Međutim, najčešće se primjenjuje pojednostavnjeni koncept modeliranja kod kojega se ponašanje lijevog i desnog priključka modelira zasebnim rotacijskim oprugama odgovarajuće krutosti na savijanje, pri čemu karakteristike moment-rotacija pojedine opruge u obzir uzimaju ponašanje hrptenog panela izloženog posmiku te utjecaj odgovarajućih spojeva. Time se modeliranje dvostranih priključaka svodi na zasebno modeliranje dvaju jednostranih priključaka koji su u interakciji, a na ovome principu najčešće rade i specijalizirani programi za određivanje proračunskih karakteristika priključaka. Zbog pojednostavnjenja proračuna, utjecaj ponašanja hrptenog panela izloženog posmiku, pri proračunu karakteristika pojedine rotacijske opruge, uzima se pomoću transformacijskih parametara $\beta_{1}$ i $\beta_{2}$ za lijevu, odnosno desnu stranu priključka (slika $5 d$ ). 
Tablica 1 - Vrijednosti transformarcijskih parametara $\beta$

\begin{tabular}{|c|c|c|c|}
\hline \multicolumn{1}{|c||}{ Tip priključka } & Sile & $\begin{array}{c}\text { Vrijednost } \\
\text { parametra } \beta\end{array}$ \\
\hline & & & \\
\hline
\end{tabular}

\section{$4 \quad$ Numerički primjer}

\subsection{Općenito}

Za ilustraciju primjene metode komponenti na proračun spregnutih priključaka obrađen je numerički primjer, slika 6. Geometrijske karakteristike konstrukcijskih elemenata u priključku i kvalitete materijala dane su u tablicama $2 \mathrm{i}$ 3.

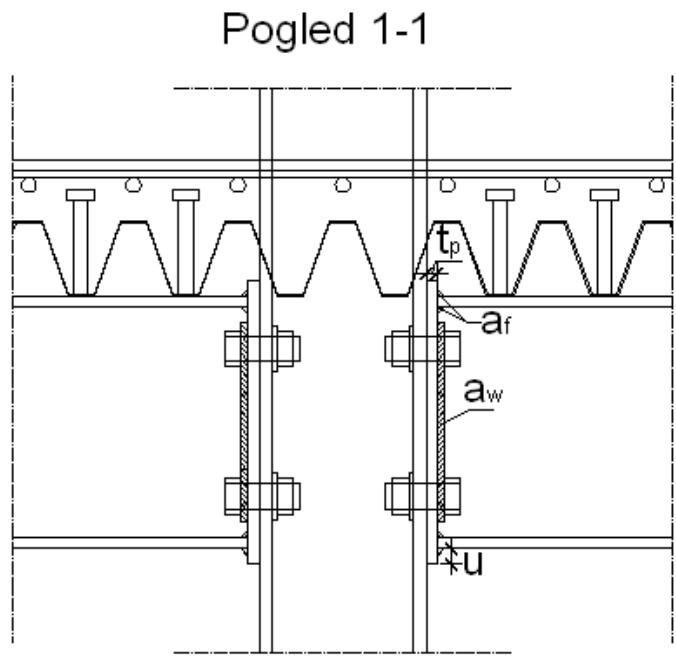

Pogled 2-2

Tlocrt
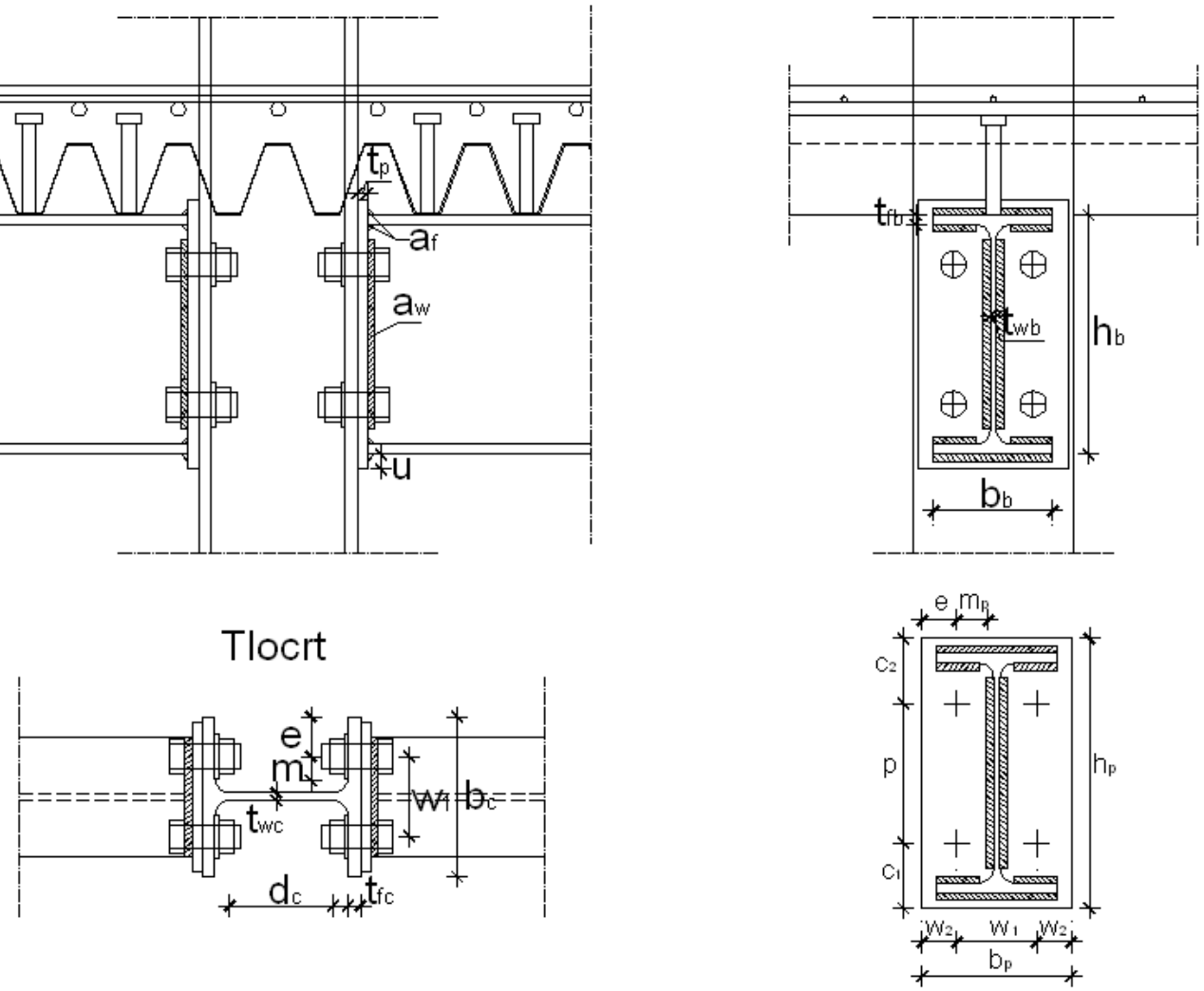

Slika 6 - Dvostrani priključak 
Tablica 2 - Karakteristike materijala

\begin{tabular}{|c|c|c|c|c|}
\hline $\begin{array}{c}\text { Stup } \\
\text { Greda } \\
\text { Čelna ploča }\end{array}$ & Vijci M24 & Beton & Armatura & Moždanici \\
\hline \hline 235 & klasa 8.8 & C 30/37 & S 400 & \\
\hline$f_{y, w c}=235 \mathrm{~N} / \mathrm{mm}^{2}$ & $f_{y b}=640 \mathrm{~N} / \mathrm{mm}^{2}$ & $f_{c d}=20 \mathrm{~N} / \mathrm{mm}^{2}$ & $f_{y d}=347,8 \mathrm{~N} / \mathrm{mm}^{2}$ & $f_{u}=450 \mathrm{~N} / \mathrm{mm}^{2}$ \\
$f_{u, f c}=360 \mathrm{~N} / \mathrm{mm}^{2}$ & $f_{u b}=800 \mathrm{~N} / \mathrm{mm}^{2}$ & & \\
\hline
\end{tabular}

Tablica 3 - Geometrijske karakteristike konstrukcijskih elemenata priključka

\begin{tabular}{|c|c|c|c|}
\hline Stup & Greda & Ċelna ploča & Vijci \\
\hline HEB 160 & IPE 240 & $270 \times 150 \times 10$ & M 4×24 \\
\hline$h_{c}=160 \mathrm{~mm}$ & $h_{b}=240 \mathrm{~mm}$ & $h_{p}=270 \mathrm{~mm}$ & \\
\hline$b_{c}=160 \mathrm{~mm}$ & $b_{b}=120 \mathrm{~mm}$ & $b_{p}=150 \mathrm{~mm}$ & \\
\hline$t_{f c}=13 \mathrm{~mm}$ & $t_{f b}=9,8 \mathrm{~mm}$ & $t_{p}=10 \mathrm{~mm}$ & \\
\hline$t_{w c}=8 \mathrm{~mm}$ & $t_{w b}=6,2 \mathrm{~mm}$ & $e_{p}=35 \mathrm{~mm}$ & \\
\hline$d_{c}=104 \mathrm{~mm}$ & $d_{b}=190,4 \mathrm{~mm}$ & $w_{1}=80 \mathrm{~mm}$ & $d=24 \mathrm{~mm}$ \\
\hline$r_{c}=15 \mathrm{~mm}$ & $r_{b}=15 \mathrm{~mm}$ & $w_{2}=35 \mathrm{~mm}$ & $d_{o}=26 \mathrm{~mm}$ \\
\hline$A_{c}=54,25 \mathrm{~cm}^{2}$ & $A_{b}=39,12 \mathrm{~cm}^{2}$ & $u=15 \mathrm{~mm}$ & \\
\hline$I_{y, c}=2492 \mathrm{~cm}^{4}$ & $I_{y, b}=3892 \mathrm{~cm}^{4}$ & $c_{1}=65 \mathrm{~mm}$ & \\
\hline$W_{p l}=354,0 \mathrm{~cm}^{3}$ & $W_{p l}=366,6 \mathrm{~cm}^{3}$ & $\begin{array}{l}p=140 \mathrm{~mm} \\
c_{2}=65 \mathrm{~mm}\end{array}$ & \\
\hline Armatura uzdužna & Armatura poprečna & Moždanici & Zavari \\
\hline$\phi 14$ & $\phi 8$ & $\phi 19$ & \\
\hline $\begin{array}{l}A_{s}=153,94 \mathrm{~mm}^{2} \\
\text { razmak } 10 \mathrm{~cm}\end{array}$ & $\begin{array}{l}A_{s}=50,27 \mathrm{~mm}^{2} \\
\text { razmak } 15 \mathrm{~cm}\end{array}$ & $\begin{array}{l}L=100 \mathrm{~mm} \\
d=19 \mathrm{~mm} \\
\text { razmak } 10 \mathrm{~cm}\end{array}$ & $\begin{array}{l}a_{f}=5 \mathrm{~mm} \\
a_{w}=5 \mathrm{~mm}\end{array}$ \\
\hline
\end{tabular}

Zbog ograničene veličine rada ovdje ćemo prikazati proračun otpornosti i krutosti komponente vlačne armature u spregnutom priključku, dok će se za ostale komponente navesti samo proračunate vrijednosti u skladu s [2]. Za više pogledati [5]. Minimalna količina armature određuje se prema izrazu 6, pri čemu je usvojena efektivna širina betonske ploče $b_{e f f, b}=1000 \mathrm{~mm}$, a visina betonske ploče iznad profiliranog čeličnog lima iznosi $d_{\text {eff }}=69 \mathrm{~mm}$.

$A_{s, \min }=0,004 \cdot d_{\text {eff }} \cdot\left(b_{\text {eff }, b}-b_{c}\right)=0,004 \cdot 69 \cdot(1000-160)=231,84 \mathrm{~mm}^{2}$

Usvojene su armaturne šipke promjera 014 mm na razmaku od 100 mm, pa je ukupna površina poprečnog presjeka uzdužne armature:

$A_{s}=\frac{d^{2} \cdot \pi}{4} \cdot 10=\frac{14^{2} \cdot \pi}{4} \cdot 10=1539,38 \mathrm{~mm}^{2}$ 
Otpornost uzdužne čelične armature u vlaku:

$$
F_{R d}=\frac{A_{s} \cdot f_{s k}}{\gamma_{s}}=\frac{1539,38 \cdot 400}{1,15}=535436,52 \mathrm{~N}=535,44 \mathrm{kN}
$$

Rotacijska krutost uzdužne čelične armature u vlaku:

za slučaj $M_{b 1, E d}=M_{b 2, E d} \quad \Rightarrow \quad k_{\text {arm }}=\frac{A_{s}}{\frac{h}{2}}=\frac{1539,38}{\frac{160}{2}}=19,24 \mathrm{~mm}$

gdje je:

$h$ - visina čeličnog profila stupa.

\subsection{Proračunska otpornost}

Prvo je potrebno odrediti najmanje vrijednosti tlačnih i vlačnih komponenti priključka:

$$
\begin{aligned}
& F_{c, R d}=\min \begin{cases}F_{c, w c, R d} & (\text { hrbat stupa u tlaku) } \\
F_{c, f b, R d} & \text { (pojasnica grede u tlaku) }\end{cases} \\
& F_{t, R d}=\min \begin{cases}F_{t, w c, R d} & \text { (hrbat stupa u vlaku) } \\
F_{T, 1, R d} & \text { (pojasnica stupa u savijanju) } \\
F_{T, 1, R d} & \text { (čelna ploča u savijanju) } \\
F_{t, w b, R d} & \text { (hrbat grede u vlaku) } \\
F_{t, R d} & \text { (vijci u vlaku) }\end{cases} \\
& \text { [5]: } \\
& F_{c, R d}=348,51 \mathrm{kN} \\
& F_{t, R d}=139,12 \mathrm{kN} \\
& F_{R d}=535,44 \mathrm{kN}
\end{aligned}
$$

Krak unutarnjih sila $z$ određuje se ovisno o ponašanju sustava, općenito se pretpostavlja da armatura otkazuje prva, a potom vijci. Nakon toga se uspoređuju nosivosti minimalne tlačne komponente i nosivost armature. U ovom slučaju je $F_{c, R d}<F_{R d}$ pa slijedi da je:

$$
z=h_{b}-\frac{t_{f b}}{2}+d-d_{1}=240-\frac{9,8}{2}+130-24=341,1 \mathrm{~mm}
$$

gdje je:

$d$ - debljina betonske ploče

$d_{1}$ - debljina zaštitnog sloja

$h_{b}$ - visina grede

$t_{t b}$ - debljina pojasnice grede

Tablica 4 - Rezultati proračuna osnovnih komponenti priključka

\begin{tabular}{||l||c||c||}
\hline \multicolumn{1}{|c||}{ Komponenta } & Proračunska otpornost & Proračunska krutost \\
\hline \hline Hrbat stupa izložen posmiku & $V_{w p, R d}=214,79 \mathrm{kN}$ & $k_{1}=\infty$ \\
\hline Hrbat stupa u tlaku & $F_{c, w c, R d}=348,507 \mathrm{kN}$ & $k_{2}=2,83 \mathrm{~mm}$ \\
\hline Hrbat stupa u vlaku & $F_{t, w c, R d}=178,72 \mathrm{kN}$ & $k_{3}=5,82 \mathrm{~mm}$ \\
\hline Pojasnice stupa izložena savijanju & $F_{T, 1, R d}=203,04 \mathrm{kN}$ & $k_{4}=15,45 \mathrm{~mm}$ \\
\hline Čelna ploča izložena savijanju & $F_{T, 1, R d}=139,12 \mathrm{kN}$ & $k_{5}=5,46 \mathrm{~mm}$ \\
\hline Pojasnica i hrbat grede u tlaku & $F_{c, f b, R d}=374,24 \mathrm{kN}$ & $k_{7}=\infty$ \\
\hline Hrbat grede u vlaku & $F_{t, w b, R d}=269,46 \mathrm{kN}$ & $k_{8}=\infty$ \\
\hline Vijci u vlaku & $F_{t, R d}=406,66 \mathrm{kN}$ & $k_{10}=12,84 \mathrm{~mm}$ \\
\hline Uzdužna čelična armatura u vlaku & $F_{R d}=535,44 \mathrm{kN}$ & $k_{a r m}=19,24 \mathrm{~mm}$ \\
\hline
\end{tabular}


U proračun karakteristika priključka ulaze zasjenčane komponente i to na način:

$F_{R d}=\min \left\{\begin{array}{lc}F_{c, w c, R d} \quad(\text { hrbat stupa u tlaku }) \\ V_{w p, R d} \quad(\text { hrbat stupa u posmiku }) \\ F_{R d, a r m}+F_{t, R d} \quad(\text { arm. }+ \text { min. vl. komp. })\end{array}\right.$

Iz tablice se vidi da je mjerodavna komponenta za proračun otpornosti priključka:

$$
F_{R d}=V_{w p, R d}=214,79 \mathrm{kN}
$$

Plastična otpornost priključka:

$M_{R d}=F_{R d} \cdot z=\frac{214,79 \cdot 341,1}{1000}=73,26 \mathrm{kNm}$

Elastična otpornost priključka:

$M_{e, R d}=\frac{2}{3} \cdot M_{R d}=\frac{2}{3} \cdot 73,26=48,84 \mathrm{kNm}$

\subsection{Proračunska krutost priključka}

Prema slici 4. potrebno je odrediti mjerodavan krak sila $Z_{e q}$ :

$$
\begin{aligned}
& k_{t}=\frac{1}{\sum \frac{1}{k_{i}}}=\frac{1}{\frac{1}{5,82}+\frac{1}{15,45}+\frac{1}{5,48}+\frac{1}{\infty}+\frac{1}{12,84}}=2,0124 \mathrm{~mm} \\
& k_{\text {eff }, r, 1}=k_{\text {arm }}=19,24 \mathrm{~mm} \\
& k_{\text {eff }, r, 2}=k_{t}=2,0124 \mathrm{~mm} \\
& z_{e q}=\frac{\sum k_{e f f, r} \cdot h_{r}^{2}}{\sum k_{e f f, r} \cdot h_{r}}=\frac{k_{a r m} \cdot h_{1}^{2}+k_{t} \cdot h_{2}^{2}}{k_{\text {arm }} \cdot h_{1}+k_{t} \cdot h_{2}}=\frac{19,24 \cdot 341,1^{2}+2,01 \cdot 185,1^{2}}{19,24 \cdot 341,1+2,01 \cdot 185,1}=332,731 \mathrm{~mm} \\
& k_{\text {eq }}=\frac{\sum_{n} k_{\text {eff }, r} \cdot h_{r}}{z_{\text {eq }}}=\frac{k_{\text {arm }} \cdot h_{1}+k_{t} \cdot h_{2}}{z_{e q}}=\frac{19,24 \cdot 341,1+2,01 \cdot 185,1}{332,731}=20,84 \mathrm{~mm} \\
& S_{j, \text { ini }}=\frac{E \cdot z_{e q}^{2}}{\frac{1}{k_{1}}+\frac{1}{k_{2}}+\frac{1}{k_{e q}}}=\frac{210000 \cdot 332,731^{2}}{\frac{1}{\infty}+\frac{1}{2,83}+\frac{1}{20,84}}=5,79284 \cdot 10^{10} \mathrm{Nmm} / \mathrm{rad}=57928,4 \mathrm{kNm} / \mathrm{rad} \\
& S_{j}=\frac{S_{j, \text { ini }}}{2}=28964,2 \mathrm{kNm} / \mathrm{rad}
\end{aligned}
$$

Dakle, proračunske karakteristike spregnutog priključka koje bi se mogle koristiti u globalnom proračunu konstrukcije su:

$$
\begin{aligned}
& M_{R d}=73,26 \mathrm{kNm} \\
& M_{e, R d}=48,84 \mathrm{kNm} \\
& S_{j, \text { ini }}=57928,4 \mathrm{kNm} / \mathrm{rad} \\
& S_{j}=28964,2 \mathrm{kNm} / \mathrm{rad}
\end{aligned}
$$




\section{Zaključak}

U radu se opisuje način modeliranja i proračuna priključaka kod spregnutih konstrukcija čelik-beton prema Eurokod normama [2] i [3]. Pri određivanju proračunskih karakteristika priključaka koristi se metoda komponenata koja se sastoji u tome da se priključak modelira sustavom sastavljenim od krutih i popustljivih komponenata, pri čemu se za svaku komponentu priključka određuju karakteristike otpornosti, krutosti i duktilnosti. Ponašanje priključka dobije se povezivanjem komponenti u cjelinu.

$\mathrm{U}$ radu se daje numerički primjer proračuna dvostranog spregnutog priključka s čelnom pločom. Specifičnost spregnuth priključaka je u tome da se u obzir mora uzeti uzdužna armatura (koje se tretira kao red vijaka), a prilikom određivanja rotacijskog kapaciteta spregnutog priključka potrebno je u obzir uzeti utjecaje raspucavanja betona, vlačnog očvršćivanja i deformaciju moždanika. $U$ radu se utjecaj ponašanja hrptenog panela izloženog posmiku uzima pomoću transformacijskih parametara $\beta_{1}$ i $\beta_{2}$.

\section{Literatura}

[1] Markulak, D. Posebna poglavlja čeličnih konstrukcija, Sveučilište J.J. Strossmayera u Osijeku, Građevinski fakultet Osijek, Osijek, 2010.

[2] HRN EN 1993-1-8:2008 Eurokod 3 -- Projektiranje čeličnih konstrukcija -- Dio 1-8: Projektiranje priključaka (EN 1993-1-8:2005+AC:2005), Hrvatski zavod za norme, Zagreb, 2008.

[3] HRN EN 1994-1-1:2008 Eurokod 4 - Projektiranje spregnutih konstrukcija od čelika i betona - Dio 1-1: Opća pravila i pravila za zgrade (EN 1994-1-1:2004), Hrvatski zavod za norme, Zagreb, 2008.

[4] HRN EN 1992-1-1:2008 Eurokod 2 -- Projektiranje betonskih konstrukcija -- Dio 1-1: Opća pravila i pravila za zgrade (EN 1992-1-1:2004+AC:2008), Hrvatski zavod za norme, Zagreb, 2008.

[5] Abičić, A.: Izračun mehaničkih karakteristika spregnutog priključka - diplomski rad. Građevinski fakultet Osijek, 2010. Voditelj: Markulak, D.

[6] HRN EN 1993-1-1:2008 Eurokod 3 -- Projektiranje čeličnih konstrukcija -- Dio 1-1: Opća pravila i pravila za zgrade (EN 1993-1-1:2005+AC:2006), Hrvatski zavod za norme, Zagreb, 2008.

[7] Structural Steelwork Eurocodes - Development of a Trans-National Approach: Composite joints

[8] Androić, B.; Dujmović; D.; Džeba, I.: Čelične konstrukcije 1, IA Projektiranje, Zagreb, 2009.

[9] Markulak, D.: Proračun čeličnih konstrukcija prema EN 1993-1-1, Sveučilište J.J. Strossmayera u Osijeku, Građevinski fakultet Osijek, Osijek, 2008.

[10] Markulak, D.; Ivanušić, D.: Modeliranje dvostranih priključaka u čeličnim okvirnim konstrukcijama, Građevinar 61 (2009) 11, 1047-1058

[11] Horvatić, D.: Spregnute konstrukcije čelik-beton, Masmedia d.o.o. Zagreb, 2003. 